\title{
KASVATUS\&AIKA
}

Katsaus

https://doi.org/10.33350/ka.111560

\section{Konkreetit utopiat keinona edistää nuorten kansalaisvaikuttamista}

\author{
Antti Rajala, Jarmo Lehtinen, Elina Lehtomäki, Pihla Soinnunmaa, \\ Mikael Sorri \& Riikka Suhonen
}

\section{Johdanto}

Historiallisesti pandemiat ovat pakottaneet ihmiset katkaisemaan suhteensa menneisyyteen ja kuvittelemaan maailman uudella tavalla. Tämä pandemia ei ole erilainen kuin muut. Se on portaali, portti yhden maailman ja seuraavan välillä. (Roy 2020.)

Normaaliin ei ole paluuta, väittää kirjailija Arundhati Roy, kun maailma käy yhtä aikaa läpi koronapandemian lisäksi ilmastokriisiä ja laajempaa ympäristökriisiä. Royn (2020) mukaan normaali on itsessään ongelma, ja sen hetkellinen murtuminen avaa mielikuvituksemme mahdollisuudelle toisenlaisesta maailmasta. Kansainvälisen lentoliikenteen väheneminen ja monet muut yhteiskunnalliset muutokset, jotka ennen pandemiaa olivat juuri ja juuri kuviteltavissa, todistavat, että radikaalit vaihtoehdot nykyisille elämäntavoille ovat paitsi välttämättömiä myös mahdollisia.

Tarvitaan kuitenkin vielä perustavanlaatuisempia muutoksia kaikilla yhteiskunnan tasoilla, kun ihmiskunta on ylittämässä planetaarisia rajoja (Steffen ym. 2015). YK:n biodiversiteettisopimus, Agenda 2030:n esiin tuomat kestävän kehityksen tavoitteet sekä Pariisin ilmastosopimus ovat esimerkkejä sopimuksista, joissa valtiot ovat sopineet yhteisistä tavoitteista asian ratkaisemiseksi. Kuitenkin monet tutkimukset ja raportit osoittavat, että näiden tavoitteiden saavuttamisessa ollaan epäonnistumassa ( $\mathrm{mm}$. Secretariat of the Convention on Biological Diversity 2020; Global Sustainable Development Report 2019; United Nations Environment Programme 2020). Tiederajat ylittävä kansainvälinen tutkijoiden raportti korostaa kansalaisten ja tutkijoiden osallistumista ja yhteistyötä ilmastokriisin ratkaisuun, sillä poliittiset tavoitteet ja toimet eivät riitä (Global Sustainable Development Report 2019). Ei ole liioiteltua sanoa, että ihmiskunnan pitää oppia rakentamaan uudelleen suhteensa maailmaan, jota säätelevät planetaariset rajat.

Muutaman viime vuoden aikana olemme nähneet nuorten johtaman ilmastoaktivismin nousun. Ruotsalaisen ilmastoaktivisti Greta Thunbergin viikottaiset koululakot inspiroivat nuoria ympäri maailmaa protestoimaan ja vaatimaan kiireellisiä ilmastotekoja. Nuorten lakot ovat johtaneet muun muassa kansainvälisen Fridays For Future -liikkeen syntyyn vuonna 2019. Nuorten koululakkoihin on osallistunut ympäri maailman jo 14 miljoonaa ihmistä (fridaysforfuture.org).

Nuorten globaali kollektiivinen toiminta kyseenalaistaa paitsi koulun myös valtioiden ja yhteiskuntien hitaan muutoksen. Se herättää kysymyksiä koulutuksen arvoperustasta, roo- 
lista ja toiminnasta sekä demokratiakasvatuksesta ekokriisin aikakaudella (Taylor \& PaciniKetchabaw 2015; Värri 2018). Tässä katsauksessa tarkastelemme, minkälainen pedagogiikka voisi edistää nuorten kansalaisvaikuttamista nykyisessä yhteiskunnallisessa tilanteessa, jota luonnehtii perustavanlaatuisen ja kiireellisen muutoksen tarve. Tarkemmin tutkimuksemme käsittelee 'konkreetin utopian' käsitteen pedagogisia mahdollisuuksia toisen asteen opiskelijoiden demokraattisen vaikuttamisen valmiuksien edistämisessä.

Käsittelemme ensin lyhyesti utopian käsitettä sosiologiassa ja kasvatustieteessä. Sen jälkeen esitämme luonnoksen mallista, jota olemme kehittäneet tutkimusprojektissa Konkreettien utopioiden pedagogiikka: Nuorten toimijuus ja ilmastoaktivismi opetuksessa (2020-2023). Projektin tavoite on suunnitella ja tutkia pedagogisia lähestymistapoja, joilla voidaan vastata nuorten ilmastonmuutosta koskeviin huoliin, tukea aktiivisen kansalaisuuden kehittymistä ja edistää kestävän kehityksen toimia lukioissa ja ammattikouluissa. Projektin lähestymistapana on tutkijoiden ja käytännön toimijoiden välinen yhteistyö (Penuel ym. 2020) ja se toteutetaan yhteistyössä opettajien, kansalaisjärjestöjen ja nuorten ilmastoaktivistien kanssa. Hyödynnämme suunnittelututkimuksen menetelmiä (Gutiérrez ym. 2020) uudenlaisen pedagogiikan muotoiluun ja tutkimiseen. Tämän katsauksen laadintaan ovat tutkijoiden ohella osallistuneet kaksi lukion opettajaa sekä ammatillisen oppilaitoksen kansainvälisten asioiden koordinaattori. Katsauksen lopuksi pohdimme ehdotetun pedagogisen mallin merkitystä demokratiakasvatuksen ja nuorten kansalaisvaikuttamisen edistämisessä.

\section{Utopian käsite}

Utopian käsite voidaan jäljittää 1500-luvun alkuun Thomas Moren klassikkoromaaniin Utopia (1516), jonka tapahtumat sijoittuivat fiktiiviselle Utopian saarelle. Utopioita pidetään usein ongelmallisina, ja julkisessa keskustelussa ne joko sivuutetaan epäolennaisina fantasioina tai liitetään vaarallisiin totalitaarisiin pohjapiirroksiin ihanneyhteiskunnista. Kuitenkin kaikkiin yhteiskunnallisiin teorioihin ja uskomuksiin sisältyy utooppisia aineksia ja ihanteita, joiden taustaa vasten yhteiskunnallinen kritiikki tulee ylipäänsä mahdolliseksi ja merkitykselliseksi. Myös aikamme näennäisen pragmaattisia johtoajatuksia, kuten taloudellista kasvua ja uskoa teknologian kykyyn ratkaista ongelmia, voi tarkastella kriittisesti eräänlaisina utopioina. Utopian ytimessä on "halu toisenlaiseen olemisen tapaan, yksilöllisesti ja kollektiivisesti, subjektiivisesti ja objektiivisesti. Utopian ilmaukset tutkivat ja tuovat keskusteluun ihmisen hyvinvoinnin potentiaalisia sisältöjä ja konteksteja" (Levitas 2013, xi).

Sosiologi Erik Olin Wright (2010) käytti utopian käsitettä tutkimuksissaan, joissa hän tarkasteli radikaalisti toisenlaisten instituutioiden mahdollisuuksia ja toteutettavuutta. Esimerkkeinä tällaisista "todellisista utopioista" hän mainitsi esimerkiksi osallistavan budjetoinnin, Wikipedian ja perustulon, joiden hän näki ilmentävän emansipatorisia vaihtoehtoja vallitsevalle yhteiskuntajärjestykselle. Kyse on eräänlaisista väliasemista matkalla kohti oikeudenmukaista yhteiskuntaa (Wright 2007). Wrightin mukaan todelliset utopiat voivat vakuuttaa ihmisiä uskomaan vaihtoehtoisiin, toivottuihin tulevaisuuksiin ja myös toimimaan niiden eteen. Peter Moss (2014) nojasi Wrightin ajatukseen väliasemista, kun hän kuvasi demokraattisten koulutuskokeilujen (esim. Reggio Emilia) merkitystä uusliberaalin vaihtoehdottomuuden torjumisessa. Vastaavasti Annalisa Sannino (2020) tutki ja edisti todellisten utopioiden rakentamista ratkaisuna asunnottomuuden ongelmaan yhteistyössä palkittujen suomalaisten sosiaalityön projektien kanssa. 
Tässä tutkimuksessa viittaamme konkreetin utopian käsitteellä ei vain vaihtoehtoisten tulevaisuuksien kuvitteluun, vaan myös toteuttamiseen nykyhetkessä osana formaalia opetusta. Konkreettien utopioiden idea on tarttua nykytilanteeseen sisältyviin muutoksen mahdollisuuksiin; ne eroavat epäkäytännöllisistä kuvitelmista, joina utopiat usein ymmärretään ja joita voidaan luonnehtia myös abstrakteiksi utopioiksi (Bloch 1986). Ero konkreetin ja abstraktin utopian välillä on kuitenkin liukuva. Myös abstrakteilla utopioilla on tärkeä tehtävä herätellä halua ja toivoa paremmasta maailmasta. Hyödynnämme tutkimuksessamme erityisesti sosiologi Ruth Levitasin utopian käsitteen uudelleentulkintaa, johon pohjautuen ymmärrämme utopiat dialogisina, moninaisina ja alati keskeneräisinä (Levitas 2013; Rajala 2021; Rajala ym. 2020).

\section{Konkreettien utopioiden pedagogiikka}

Tässä katsauksessa ehdottamamme pedagoginen malli on esitetty kuviossa 1 . Se perustuu vapaaseen pedagogiseen tulkintaan Levitaksen (2013) esittämästä sosiologisesta utopiametodista ja koostuu kolmesta toisiinsa kietoutuvasta elementistä: utopioiden arkeologia, utopioiden rakentaminen sekä utopioiden arvioiminen ja tarkentaminen demokraattisessa dialogissa. Näitä mallin osia voidaan ottaa käyttöön opetuksessa esimerkiksi niin, että koulun utopiaprojekti perustuu vain yhteen tai kahteen mallin osaan, tai isommassa projektissa kaikkiin kolmeen. Seuraavaksi käsittelemme erikseen kutakin pedagogisen mallin osaa.

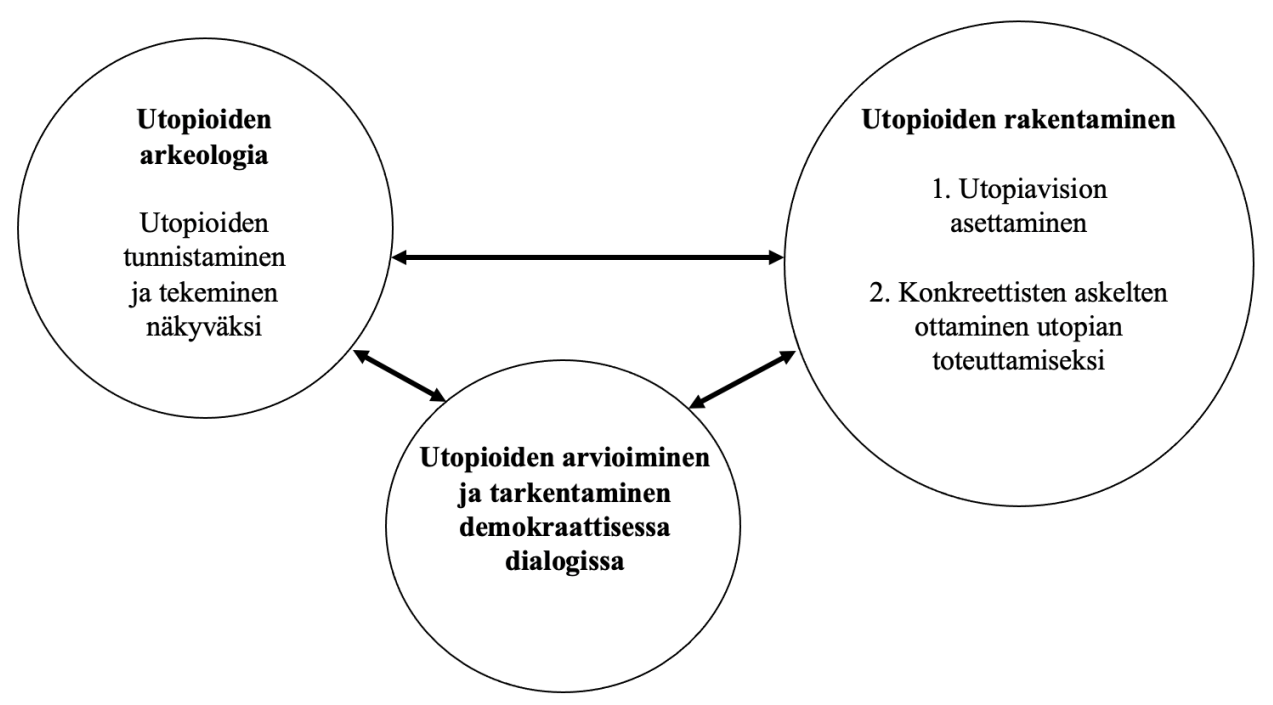

Kuvio 1. Konkreettien utopioiden pedagogiikan teoreettinen malli.

\section{Utopioiden rakentaminen}

Utopia ilmentää halua ja toivoa paremmasta (Bloch 1986), mikä edellyttää kykyä kuvitella vaihtoehtoja nykyiselle yhteiskunnalliselle todellisuudelle. Konkreettien utopioiden pedagogiikkaan kuuluu radikaalien vaihtoehtojen ja utopia-visioiden esittäminen ja tutkiminen. Seuraavassa Lempäälän lukion opettaja Jarmo Lehtinen esittelee Megatrendit-kurssiaan, 
jossa opiskelijat muodostivat omia utopia-visioitaan Suomen itsenäisyyden juhlarahasto Sitran asiantuntijan Liisa Poussan tukemana.

Syksyllä 2020 lukiossamme oli ensi kertaa tarjolla soveltavan historian Megatrendit-kurssi. Siinä huomio on aikamme suurissa ilmiöissä, ja muista kursseista poiketen perspektiivi on menneisyyden sijaan tulevassa. Kurssin suunnittelua helpotti se, että Sitralla oli valmiina oivallinen Megatrendit 2020 tietopaketti. Erityisen hienoa oli, että saimme kurssille mukaan kyseistä pakettia koonneen ennakointiasiantuntija Liisa Poussan. Liisa jakoi opiskelijoille lisäaineistoja ja piti Megatrendejä käsittelevän luennon, jonka aikana hän kertoi esimerkiksi, miten koronaepidemia on vaikuttanut 2020-luvun tulevaisuusnäkymiin.

Megatrendit 2020 -esityksessä keskitytään viiteen teemaan: ekologinen jälleenrakentaminen, väestön ikääntyminen ja monimuotoistuminen, verkostoituva valta, teknologinen murros sekä uusi taloudellinen järjestelmä. Kurssin opiskelijat jaettiin viiteen ryhmään, ja jokaiselle ryhmälle annettiin yksi edellä mainituista teemoista. Teemat käytiin kurssin aikana järjestyksessä läpi siten, että käytimme Sitran esityksen tilastoja ja etsimme muita teeman kannalta olennaisia faktoja. Pyrimme jokaisella oppitunnilla etsimään vastauksia siihen, miten eri teemat näkyvät ajankohtaisissa ilmiöissä.

Jokaisen ryhmän tehtävänä oli koostaa oma teemansa utopia-julisteeksi, jossa keskiössä olisi vuosi 2030 ja tilanne, jossa teemaan liittyvät haasteet olisi onnistuttu ratkaisemaan. Julisteiden tekemiseen annettiin aikaa jokaisen oppitunnin lopulla. Jokaisella tunnilla oli myös tarkoitus tarjota evästeitä jokaiselle ryhmälle, vaikka tunnin aiheena olisi ollut joku muu teema. Ohjeistuksena oli, että julisteisiin pyrittäisiin löytämään positiivinen näkymä. En halunnut, että nuoret jäisivät liiaksi kiinni olemassa oleviin ongelmiin, jotka tukkivat ajattelumme tässä päivässä, kuten lihasta luopuminen.

Kurssin päätteeksi käytiin läpi ryhmien tuotokset, joita Liisa Poussa kommentoi. Viimeisellä oppitunnilla kaikki teemat ja erilaiset näkökulmat tiivistettiin yhteen julisteeseen (ks. Kuvio 2), jossa ryhmäläiset tiivistivät oman teemansa yhteen avainkysymykseen ja pohtivat, mikä on paras kuviteltavissa oleva vastaus siihen.

Tulevaisuusperspektiivi näyttää loistavan poissaolollaan lukiomme kurssitarjonnassa. Johtuuko se siitä, että tulevaisuus vaikuttaa synkältä vai siitä, että emme halua lukiossa tarttua mihinkään, mistä ei ole selkeitä faktoja? Erityisen hankala aihealue on ilmastonmuutos, koska siihen liittyviä erilaisia skenaarioita on paljon ja tutkijat vaikuttavat olevan yhtä mieltä ainoastaan siitä, että muuttujien suuren määrän vuoksi kukaan ei tiedä vastauksia.

Haastavinta Megatrendit-tyylisen kurssin suhteen voikin opettajan näkökulmasta olla juuri se, että hän ei voi esiintyä teemassa asiantuntijana. Toisaalta on äärettömän hedelmällistä asettua nuorten kanssa pähkäilemään erilaisia skenaarioita. Kurssin jälkeen kootussa palautteessa moni nuori koki kuitenkin haastavimmaksi, jopa ahdistavaksi sen, että elämme epätietoisuudessa ja ainoa, mistä voimme olla varmoja on se, että asiat tulevat muuttumaan. Tulevaisuusahdistus tuli kurssin varrella puheeksi useaan otteeseen. 
Opettajana opin jälleen kerran sen, että ryhmien työskentelyä ei kannata liikaa ohjata; lopputuotosten on oltava opiskelijoiden näköisiä. Asiantuntijan roolista luopuminenkin on vaikeaa mutta toisaalta antoisaa. Koronakriisi on osoittanut meille, että mustia joutsenia on olemassa. Ja koska odottamattomia tapahtumia tapahtuu, kehitys saattaa pitkällä tähtäimellä johtaa hyviinkin lopputulemiin. Tulevaisuuden pohtiminen ei ole pelkästään uhkakuvien maalaamista.

Projekti havainnollistaa, että utopia-työskentely korostaa opiskelussa usein vähemmälle huomiolle jäänyttä näkökulmaa positiivisista tulevaisuudenkuvista. Erityisesti ilmastonmuutokseen liittyen julkisessa keskustelussa painottuvat tulevaisuuteen liittyvät uhat, pelot ja ilmastoahdistus (ks. myös Piispa ym. 2020), joihin utopioiden käsittely voi tuoda vastapainoa. Eräässä tutkimusprojektiimme osallistuvassa lukiossa kirjasto oli opettajan pyynnöstä laittanut esille dystopioiden ohella utopiakirjallisuutta. Kirjaston työntekijät olivat kokeneet tehtävän mielekkääksi ja uudenlaiseksi näkökulmaksi.

Samalla Megatrendit-projekti nostaa esiin utopia-työskentelyn haasteita. Koulun tehtävässä painottuu tutkittu ja faktapohjainen tieto; sekä opettaja että opiskelijat kokivat utopiavision muodostamiseen liittyvän spekulatiivisen tiedon tuottamisen ja käsittelyn vaikeaksi. Lehtisen mukaan lukion tiivis opiskelutahti jättää vähemmän tilaa luovuudelle kuin aiemmat kouluasteet. Lisäksi lukion oppimateriaaleista voi nykyisellään olla vaikea löytää riittävästi aineksia utopia-visioiden muodostamiseen. Projektissa hyödynnetyt Sitran materiaalit ja asiantuntijan tuki olivat opettajan mukaan hyvin tarpeellisia. Kaiken kaikkiaan vaikeuksista huolimatta opiskelijat kokivat työskentelyn palkitsevana ja merkittävällä tavalla normaalista koulutyöstä poikkeavana. 


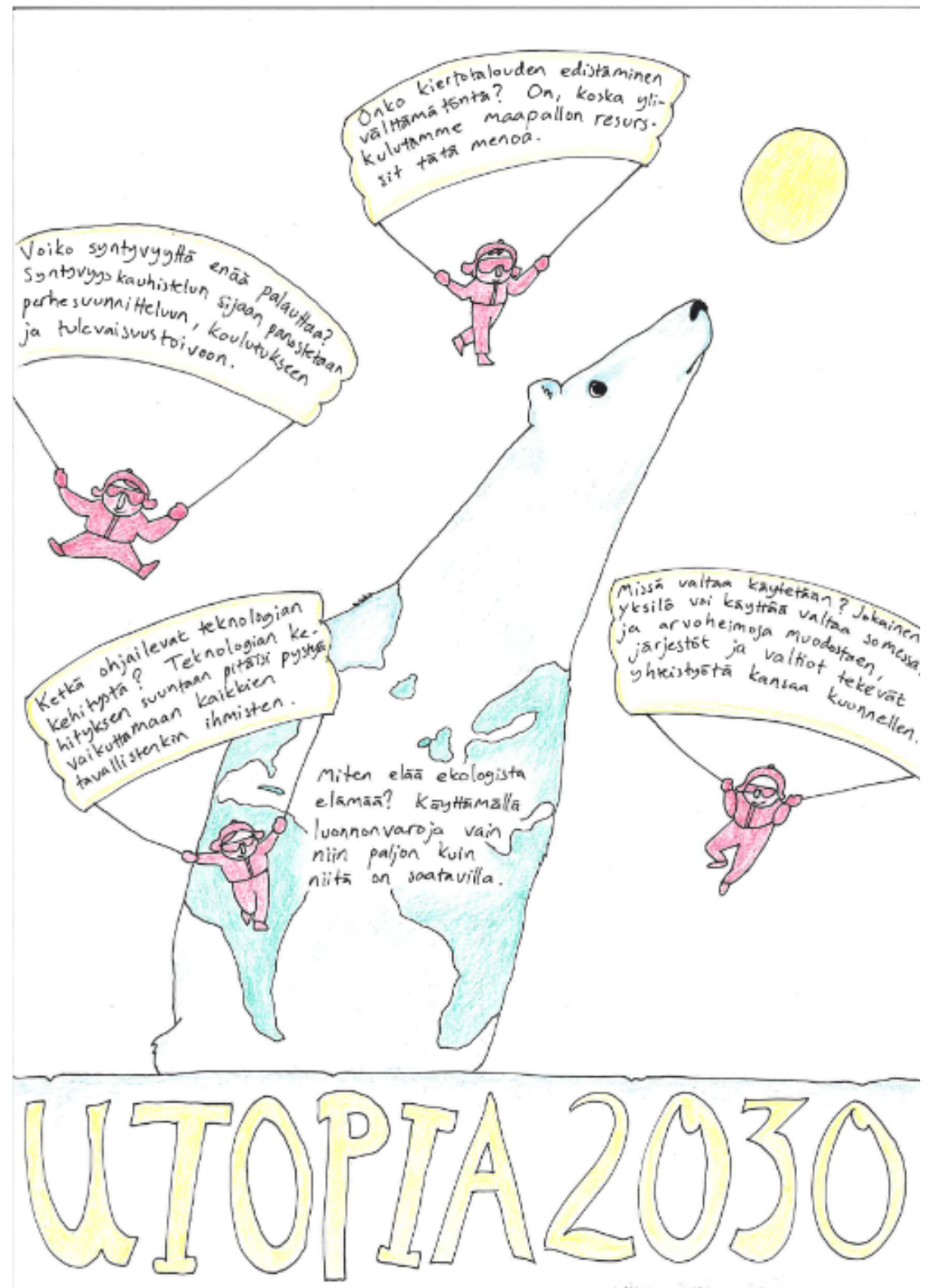

Kuva 1. Megatrendit-projektin lopputyöt tehtiin postereina. 
Pedagogisena käsitteenä konkreetti utopia korostaa vaihtoehtoisten maailmojen visioinnin lisäksi visioiden konkretisointia. Yksinkertaisimmillaan tämä voi tarkoittaa vaihtoehtoisen maailman yksityiskohtien kuvittelua ja esittämistä kirjoittamalla tai taiteellisen työskentelyn avulla. Esimerkiksi rauhan- ja konfliktintutkimuksen pioneerin, sosiologi Elise Bouldingin työpajoissa kuviteltiin, minkälainen voisi olla aseeton maailma (Dufva ym 2021; Boulding, 1976). Työpajojen idea perustui Bouldingin havaintoon, että aseistariisunnan asiantuntijat eivät osanneet vastata kysymykseen, miten aseeton maailma toimisi ja miltä se näyttäisi.

Utopia-vision toteuttamiseksi voidaan ottaa myös konkreettisia askeleita osana opetusta, tekemällä kokeiluja nykyhetkessä. Opiskelijat voivat esimerkiksi suunnitella ja toteuttaa kansalaisvaikuttamisen projektin yhdessä opettajiensa ja koulun ulkopuolisten tahojen kanssa. Tällaisissa utopia-projekteissa halutaan muuttaa nykyisiä elintapoja ja toiminnan järjestämisen muotoja. Esimerkkinä tarkastelemme seuraavassa Etelä-Tapiolan lukion Fillarit Liikkeelle! -projektia. Esittelemme projektin sen opettajan Mikael Sorrin sanoin:

Fillarit Liikkeelle! oli Etelä-Tapiolan lukiossa lukuvuosina 2009-2012 toteutettu kaupunkiympäristöjen tutkimus- ja kehittämisprojekti. Se toteutettiin osana yhteiskuntaopin soveltavaa kurssia YH14 Kestävä kehitys. Projektin alkuperäisenä tavoitteena oli tutkia ja kehittää pyöräilykulttuuria pääkaupunkiseudulla.

Keväällä 2010 Alankomaiden Rotterdamin ympäristöön sekä Amsterdamiin suuntautuneen kaupunkitutkimusmatkan aikana projektin opettajien ja opiskelijoiden ymmärrys pyöräilykulttuureista ja niiden eroista syveni. Opettajat hankkivat lisää ymmärrystä asiasta osallistumalla seminaareihin ja koulutuksiin, joissa puhuttiin ja kannustettiin paradigman muutokseen. Paradigman muutoksella tarkoitettiin sitä, että Suomessakin on aika siirtyä pyöräliikenteen suunnittelussa kohti Keski-Euroopassa hyväksi havaittuja ratkaisuja.

Fillarit Liikkeelle! -projektissa syntyi yhteisiä oivalluksia pyöräilyinfran laadun keskeisestä merkityksestä hyvälle pyöräilykulttuurille. Ymmärsimme myös, että rakenteilla olleen Länsimetron myötä tivvistyvän Espoon pyöräteiden laatu ei vastaa nykyhetken eikä varsinkaan tulevaisuuden tarpeisiin. Oivallukset johtivat toimintaan.

Opiskelijat ja opettajat laativat yhdessä ja toisinaan erikseen muistutuksia ja mielipidekirjoituksia, joissa he vaativat parempaa infraa. Esimerkkinä tästä on ote erään projektin opiskelijan Espoon kaupunginvaltuustolle lähettämästä sähköpostista: "Hyvä kaupunginvaltuusto ... Erityisesti sellaiset ratkaisut, kuten yhdistetty kävely- ja pyörätie, ovat jo vanhentuneita malleja. Harvaan liikennöidyllä reitillä yhdistetty malli saattaa toimia hyvinkin, mutta harva reitti Espoon osakeskuksissa on enää harvaan liikennöity. Erilliset pyörä- ja jalkakäytävät ovat tulevaisuutta. Tämä on ymmärretty Amsterdamissa, Kööpenhaminassa, Lontoossa ja Helsingissäkin...."

Ainakin yhden kerran oma muistutuksemme yhdessä Helsingin Pyöräilijöiden eli HePo:n samansuuntaisen muistutuksen'1 kanssa johti siihen, että eräs Lep-

1 Ks. https://www.kaupunkifillari.fi/2011/08/16/espoon-pyoraliikenteen-suunnittelu/ ; http://www.etelatapiola.fi/news/276/231/Fillarit-Liikkeelle-projekti-vaikutti-Espoon-katusuunnitelmiin/ 
pävaaran juna-aseman lähelle sijoittunut katusuunnitelma jätettiin Espoon teknisen lautakunnan kokouksessa pöydälle. Myöhemmin katuosuus päätettiin toteuttaa ja toteutettiin pitkälti ehdottamallamme tavalla. Idean ehdotukseemme olimme saaneet Alankomaiden matkallamme Rotterdamin rautatieaseman kulmilla.

Espoon kaupungin virkamiesten keskuudessa projektimme ehdotuksineen otettiin vastaan hyvin vaihtelevasti. Parhaimmillaan sparrauksemme koettiin myönteiseksi. Pääsimme keskustelemaan erilaisiin tilaisuuksiin ja tekemään esimerkiksi liikennelaskentoja yhdessä liikenneinsinöörin kanssa. Mutta kohtasimme myös täysin päinvastaisia kokemuksia. Ikävimmillään opettajia syytettiin opiskelijoiden aivopesemisestä.

Vastoinkäymisistä huolimatta Fillarit Liikkeelle! -projektin keskeiseksi tavoitteeksi tarkentui vähitellen se, että Espooseen pitää saada sellaiset pyöräliikenteen suunnitteluohjeet, jotka mahdollistavat yhtä laadukkaan infran syntymisen kuin Alankomaissa. Kyseessä oli tavoite, joka noihin aikoihin oli jo todellisuutta Alankomaiden kaupungeissa ja joka alkoi vähitellen toteutua myös Suomen kaupungeissa, aluksi lähinnä Helsingissä. Espoossa näin ei kuitenkaan tapahtunut tai kehitys oli ainakin paljon hitaampaa kuin toivoimme. Vieläkään keväällä 2021 Espoolla ei ole käytössä sellaisia ohjeita, joita jo kymmenen vuotta sitten utopistisesti toivoimme.

Fillarit liikkeelle! -projektia voidaan luonnehtia konkreetin utopian rakentamiseksi, vaikka sitä ei sen toteutuksen aikana kuvattu utopia-projektiksi. Projektissa pyrittiin ajattelutapojen, sosiaalisten käytäntöjen sekä liikenteen infrastruktuurin perustavanlaatuiseen muutokseen. Sitä motivoi visio liikennesuunnittelun "paradigman muutoksesta" kohti pyöräily-ystävällistä Espoota. Projektin toteuttamisen aikana 2010-luvun taitteessa osa kaupungin virkamiehistä piti visiota utopistisena sanan negatiivisessa merkityksessä.

Alunperin projektin vision olivat muotoilleet opettajat, ja he olivat suunnitelleet sen perusteella opiskelijoille valinnaisen kurssin. Kun visio oli jo valmiiksi asetettu, projektissa oli aikaa keskittyä konkreettisiin askeliin vision toteuttamiseksi. Opiskelijat tekivät esimerkiksi virallisia muistutuksia katusuunnitelmista, kirjoittivat mielipidekirjoituksia, ottivat yhteyttä kaupungin virkahenkilöihin (ks. Kuvio 3) ja kaupunginvaltuustoon sekä osallistuivat suunnittelukilpailuihin. Virkamiesten vastustuksesta huolimatta opiskelijoiden ja Helsingin polkupyöräilijät ry:n tavoite Leppävaaran aseman seudun muuttamisesta pyöräilyyn soveltuvaksi lopulta toteutui. 


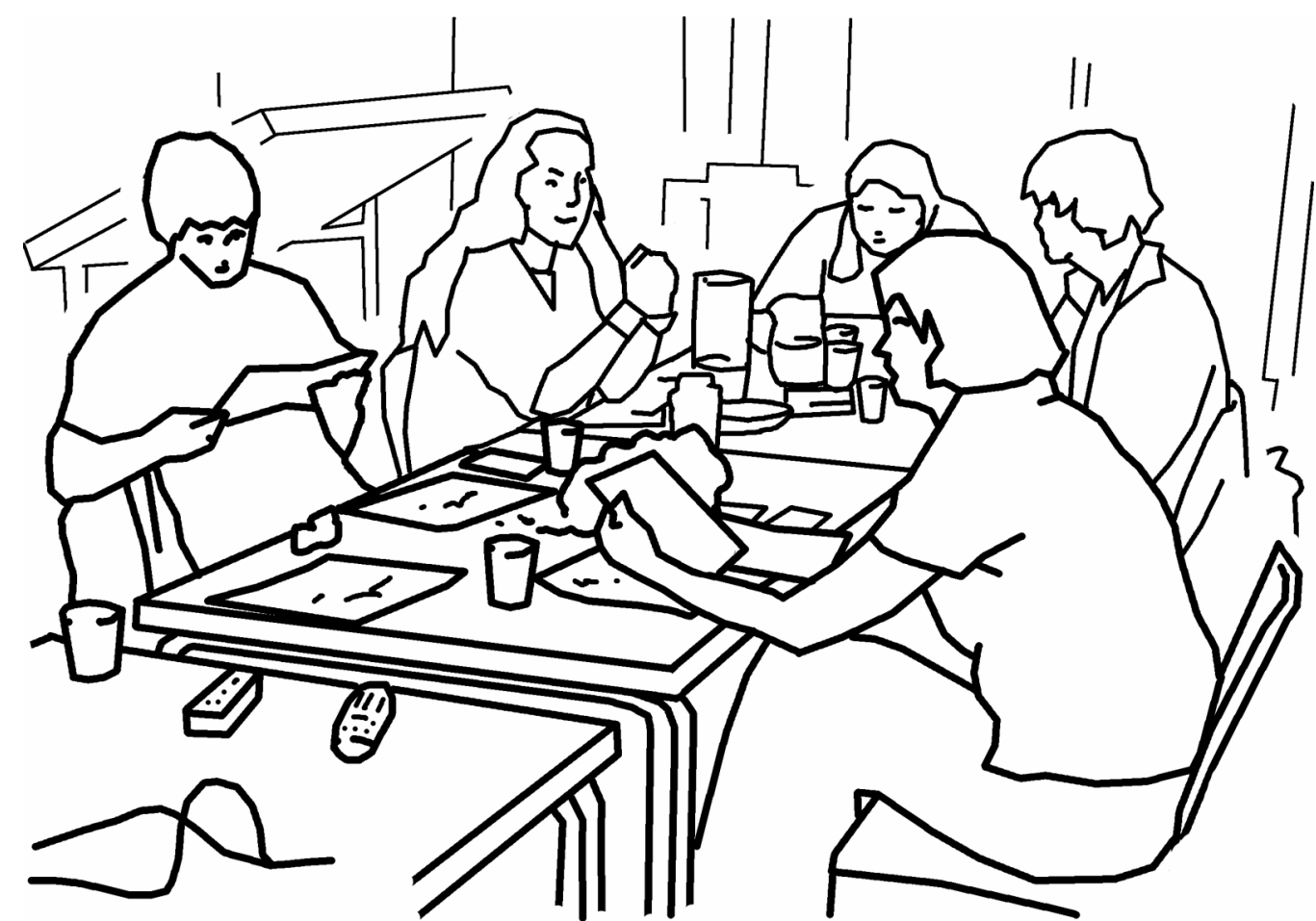

Kuva 2. Opiskelijat neuvottelevat virkahenkilöiden kanssa Tapiolan keskuksessa. Piirros valokuvan perusteella Ilmo Anundi.

\section{Utopioiden arkeologia}

Utopioiden rakentamisen lisäksi ehdotamme utopioiden arkeologiaa yhtenä konkreettien utopioiden pedagogiikan työskentelytapana. Melkein kaikkeen inhimilliseen toimintaan sisältyy halua ja toivoa paremmasta maailmasta ja tulevaisuudesta (Bloch 1986; Freire 1994). Usein tästä ei ole kuitenkaan tapana puhua utopioiden näkökulmasta. Utopioiden arkeologiassa on kyse näiden utopiaelementtien tutkimisesta ja tekemisestä näkyväksi. Fillarit liikkeelle! -projektissa tutustumista ja opintomatkaa Alankomaihin voidaan pitää utopioiden arkeologiana. Visio pyöräily-ystävällisestä kaupungista oli jo osin toteutunut Amsterdamissa ja Rotterdamissa; ja projektin idea oli samanlaisen vision toteuttaminen Suomessa.

Eräs utopioiden arkeologian toteuttamistapa, jota kokeiltiin tutkimukseemme osallistuvassa Joutsenon opistossa, oli tutustuttaa opiskelijat nuorten ilmastoliikkeeseen ja siinä toimivien aktivistien näkemyksiin tulevaisuudesta. Nuorten ilmastoaktivismi ei tarkoita vain mielenosoituksia, vaan uudenlaisen maailman yhdessä kuvittelemista ja rakentamista (Bowman 2019). Piispan, Ojajärven ja Kiilakosken (2020) tutkimuksessa tehtiin eräänlaista utopia-arkeologiaa, kun tutkijat pyrkivät selvittämään nuorten ilmastoaktivistien utopioita. Tutkijat totesivat yhteenvetona, että nuorten ilmastoaktivismia ohjasi minimitoive pikaisesta siirtymästä hiilineutraaliin yhteiskuntaan ja päästöjen merkittävään vähentämiseen. Toinen keskeinen havainto oli, että nuoret onnistuivat haastamaan ilmastosiirtymään liittyvää talouspuhetta ja muistuttamaan ilmastokriisin kiireellisyydestä. Nuoret toivat tulevaisuuskeskusteluun arvojen ja tunteiden merkityksen. Onkin tärkeää huomata, että tunteet ja 
näkemykset hyvästä elämästä ja ihmisyydestä kuuluvat olennaisena osana utopiatyöskentelyyn (Levitas 2013).

Nuoret ilmastoaktivistit haastavat opettajat, tutkijat ja päätöksentekijät: on tarpeen tutkia yhdessä nuorten kanssa heidän kuvitelmiaan - utopioitaan - erilaisista maailmoista ja tavoista ajatella ja toimia (ks. myös Bowman 2019). Opettajille aktivismi voi näyttäytyä pedagogisena haasteena: miten opettajana käsitellä ilmastonmuutosta, ristiriitaisia näkemyksiä ja kannanottoja, miten suhtautua aktivismiin kollektiivisena ilmiönä ja nuoriin oman identiteettinsä rakentajina (Leiviskä \& Pyy 2020). Tutkimusprojektissamme pidämme tärkeänä, että oppilaitosten utopiatyöskentely kiinnittyy nuorten ilmastoliikkeeseen. Projektimme työpajoissa on mukana Fridays for Future -liikkeen nuoria, jotka konsultoivat mukana olevia opettajia ja osallistuvat myöhemmin myös oppilaitosten projekteihin. Eräässä oppilaitoksessa tämä yhteistyö auttoi laajentamaan näkökulmaa projektissa, jossa opiskelijat olivat keränneet nimiä paikkakunnan lakkautuslistalla olevan juna-aseman puolesta. Keskustelu laajentui isompiin kysymyksiin, kun paikallisaseman lakkauttaminen yhdistettiin Valtion Rautateiden liiketoimintamalliin, ja sitä kautta erilaisiin talousjärjestelmiin.

\section{Utopioiden arvioiminen ja tarkentaminen demokraattisessa dialogissa}

Ehdottamassamme pedagogiikassa utopiat ymmärretään dialogisina, moninaisina ja alati keskeneräisinä (Levitas 2013). Tästä syystä utopioiden arvioiminen ja tarkentaminen demokraattisessa dialogissa on keskeinen osa konkreettien utopioiden pedagogiikkaa ja liittyy kiinteänä osana kaikkiin muihin pedagogiikan vaiheisiin.

Fillarit liikkeelle! -projektin kuluessa utopia-visio muuttui ja tarkentui kokemusten ja erilaisten keskustelujen tuloksena. Esimerkiksi Alankomaihin suuntautuneen opintomatkan aikana visiota muokattiin koskemaan laajemmin pyöräilykulttuurin edistämistä. Opettaja Sorri kuvaa asiaa seuraavasti:

Vuoden kahden päästä ymmärrettiin, ettei mikään kulttuuri voi edistyä, jos pohjalla ei ole hyvää infrastruktuuria. Se on perusta, jonka päälle voidaan rakentaa monenmoista muuta. Opimme, että kaikki muu edistäminen tulee sen jälkeen, kun infra on kunnossa. Sitä en tiedä, onko asia oikeasti näin, mutta näin se opetettiin meille alan seminaareissa. Ilman infrastruktuuria ei kummoista synny.

Jossain vaiheessa kirkastui, että infran syntyminen edellyttää hyviä suunnitteluohjeita. Hyvät suunnitteluohjeet ovat sitä insinöörikieltä. Pitää olla niin hyvät pyöräliikenteen suunnitteluohjeet, että voidaan toteuttaa se infra, insinöörit noudattavat ohjeita eivätkä lähde soveltamaan. Muuten jotain voi jäädä syntymättä siksi, että sille ei ole ohjeita.

Fillarit liikkeelle! -projekti sisälsi paljon neuvottelua eri tahojen kanssa, mikä sai myös opiskelijat ymmärtämään paremmin kaupungin virkahenkilöiden näkökulmia ja toimimaan heidän kanssaan yhteistyössä. Vaikka yhteiskunnallista muutosta tavoittelevat projektit vääjäämättä sisältävät konflikteja, voidaan dialogisella keskustelulla pyrkiä yhteisymmärrykseen. Sorri pohtii asiaa nykytilanteen näkökulmasta seuraavasti:

Espoossa Fillarit Liikkeelle! -tyyppiselle projektille aika voisi olla kypsempi nyt, sillä kaupunki on viime vuosina palkannut vuorovaikutussuunnittelijoita kaupunkisuunnitteluorganisaatioonsa. Heistä yksi on opettajataustainen Heli-Maija Nevala, joka kymmenen vuot- 
ta aiemmin toimi Fillarit Liikkeelle! -projektia inspiroineen tiedekeskus Heurekan Liikkeelle! -hankkeen projektipäällikkönä. Nevala on tällä välin kehittänyt Pelissä yhteinen kaupunki! -nimisen työpajan. Nevalan mukaan "Työpajan kaupunkiympäristö on vapaa tosielämän realiteeteista ja paikallisista jännitteistä, mikä mahdollistaa avoimen keskustelun ja ympäristöön liittyvien arvojen pohdinnan."

Ehkä konkreettien utopioiden toteuttamisessa tarvitaan aluksi ja avuksi tämäntyyppistä tosielämän realiteeteista vapaata, pelillistävää toimintaympäristöä. Yhteisissä työpajoissa on mahdollista toteuttaa vaikkapa Alankomaista tuttua pyöräliikenteen infrastruktuuria aluksi fiktiiviseen kaupunkiin. Ilman tätä välivaihetta paradigman muutosta vaativan konkreetin utopian toteuttaminen tosielämän realiteeteissa kiinni olevassa, oikeassa kaupunkiympäristössä voi olla miltei mahdotonta. Työpajojen ja vuorovaikutuksen kautta konkreetit utopiat voivat kehittyä tosielämän realiteeteiksi. Toisaalta neuvotteluissa ja joustamisessa on riskinä utopia-tavoitteen radikaalin sisällön kesyyntyminen ja toiminnan mukautuminen annettuihin raameihin (Rajala ym. 2020).

\section{Kansalaisvaikuttamisen tukeminen konkreettien utopioiden pedagogiikalla}

Kansainvälisessä International Civic and Citizenship Education Study 2016 -tutkimuksessa suomalaisnuorilla on todettu olevan erinomaiset tiedolliset valmiudet yhteiskunnalliseen osallistumiseen, mutta heikko luottamus omiin kykyihinsä yhteiskunnallisina toimijoina (Schulz ym. 2018). Luottamusta omiin kykyihin olisi syytä vahvistaa, koska sillä on todettu olevan positiivinen yhteys tulevaan aktiiviseen yhteiskunnalliseen osallistumiseen, ei vain äänestäjänä, vaan myös muilla kansalaisvaikuttamisen kentillä, kuten mielenosoituksissa (Mehtäläinen ym. 2017, 46).

Suomalainen koulujärjestelmä painottaa aktiivista kansalaisuutta lähinnä edellytyksenä ja kykynä osallistua edustukselliseen demokratiaan (Männistö 2020). Keskittyminen edustukselliseen demokratiaan saattaa olla ristiriidassa nuorten omaehtoisen aktivismin kanssa. Rautiainen ja Raiker (2020) nostavat esiin Greta Thunbergin käynnistämän globaalin ilmastoaktivismin esimerkkinä siitä, miten koulujen ja opettajien voi olla vaikeaa havaita, että aktivistit puolustavat demokratian arvoja ja oppivat tärkeitä kansalaistaitoja. Ilmastonmuutos näyttäisi herättäneen nuorten kiinnostuksen vaikuttamiseen, mutta ilmastotoiminta ei nuorten kertomusten mukaan pääsääntöisesti näyttäisi liittyvän koulun toimintaan (Ahola ym. 2021). Miten koulut voisivat tukea nuorten kasvua vaikuttajiksi ja demokraattisen yhteiskunnan toimijoiksi?

Tässä katsauksessa olemme ehdottaneet konkreettien utopioiden pedagogiikkaa uutena näkökulmana demokratia -ja kansalaiskasvatukseen. Tämän pedagogiikan tavoitteena on luoda edellytyksiä nuorille toimia niin kutsuttuina historian tekijöinä (Gutiérrez ym. 2020), jotka tarkastelevat yhteiskunnan ilmiöitä osana niiden ajallista kehitystä ja ymmärtävät itsensä yhteiskunnallisina vaikuttajina. Toisin sanoen yhteiskuntaa ja lähiympäristöä ei nähdä muuttumattomina ja staattisina, vaan osana historiallista aikaa (ks. myös Rajala ym. 2013; Bakhtin 1986). Vastaavasti tulevaisuutta ei ymmärretä vain menneisyyden ja nykyisyyden jatkumona, vaan demokraattisen ja poliittisen vaikuttamisen kohteena.

Konkreettien utopioiden pedagogiikka auttaa yhdistämään opetuksen ja opiskelijoiden yhteiskunnallisen vaikuttamisen oppilaitosten ulkopuoliseen todellisuuteen. Konkreettien utopioiden toteuttamisen vaatima muutos käytännöissä, ajattelutavoissa ja toimintatavoissa edellyttää kollektiivista toimintaa. Yhdistämällä voimat koulun ulkopuolisten tahojen kanssa voidaan projekteissa saada enemmän aikaan, kuten Fillarit liikkeelle! -hankkeen yhteis- 
työ pyöräilyaktivistien kanssa osoitti. Projekti tarjosi opiskelijoille monenlaisia tilaisuuksia kansalaisvaikuttamiseen luokan seinien ulkopuolella (ks. myös Rajala ym. 2013). He muodostivat suhteita moniin lukion ulkopuolisiin tahoihin: hankkivat vaihtoehtoisia näkökulmia haastattelemalla asiantuntijoita, solmivat liittolaisuuksia aktivistien kanssa sekä vaikuttivat päättäjiin. Tämä edellytti omien tavoitteiden ja keinojen suhteuttamista muiden toimijoiden näkökulmiin ja aikatauluihin, mikä osaltaan konkretisoi utopia-visiota. Opiskelijat, yhdessä opettajiensa kanssa, pyrkivät vaikuttamaan historialliseen muutokseen asuinalueellaan vaihtoehtoisen tulevaisuuden luomiseksi. Megatrendit-projektissa harjoiteltiin oman utopia-vision muodostamista. Vaikka kyseisessä projektissa ei suoranaisesti toimittu yhteiskunnallisina vaikuttajina, väitämme, että nykyisyyden ja tulevaisuuden hahmottaminen vaihtoehtoisten kehityskulkujen näkökulmasta luo pohjaa toimimiselle historian ja tulevaisuuden tekijänä.

Konkreettien utopioiden pedagogiikassa ei ole kyse opetuksesta sen kapeassa merkityksessä, vaan parhaimmillaan koko koulun toimintakulttuurin muokkaamisesta. Saloranta (2017) havaitsi tutkimuksessaan, että koulun toimintakulttuuri on merkittävä kestävyyskasvatuksen onnistumisen edellytys. Tutkimuksessa osoitettiin, että myönteisillä, osallistumismahdollisuuksia vahvistavilla oppimiskokemuksilla on pitkäkestoinen vaikutus sitoutumiseen kestävää kehitystä edistäviin elämäntapoihin, mutta yksittäiset tai koulukohtaiset kokemukset eivät kuitenkaan riitä saamaan aikaan tätä vaikutusta.

Utopiat ovat luonteva aihe kasvatuksessa, jossa on perimmältään kyse paremman tulevaisuuden luomisesta. Keskiössä tulee olla nuorten omat näkemykset toivottavista tulevaisuuksista. On olennaista huomioida, että vaikka usein puhutaan nuorten aktivismista ikään kuin nuorilla olisi ilmastoasioihin yhtenäinen näkemys, nuorten välillä on monenlaisia eroja. Tietojen, taitojen ja asenteiden lisäksi mahdollisuudet vaikuttaa yhteiskunnalliseen keskusteluun riippuvat sosioekonomisesta taustasta, maantieteestä - asuuko suuressa kaupungissa vai maaseudulla - sekä osallistumista tukevista rakenteista tai niiden puuttumisesta.

Vaikka Fridays for Future -liike on nostanut lasten ja nuorten kansalaisvaikuttamisen esille maailmanlaajuisesti, ainakin eurooppalaisen kyselytutkimuksen mukaan mielenosoituksiin osallistuvien nuorten tausta on varsin keskiluokkainen, ja suurimmalla osalla $(71,3$ \%) oli vähintään yksi korkeakoulutettu vanhempi (Wahlström ym. 2019, 9). Suomi ei ollut mukana tässä tutkimuksessa, mutta Nuorisobarometrin 2018 pohjalta voidaan esittää samantyyppisiä arvioita suomalaisten nuorten ilmastoaktivistien taustasta (Meriläinen \& Piispa 2020). Siinä ammattiin opiskelevista 15-19-vuotiaista nuorista 55 prosenttia koki melko paljon tai paljon ilmastohuolta verrattuna lukiolaisten 70 prosenttiin. Ammattiin opiskelevien poliittinen ja yhteiskunnallinen vaikuttaminen sekä kiinnostus politiikkaan oli huomattavasti lukiolaisia vähäisempää, eivätkä he myöskään koe tulevansa kuulluiksi, vaikka haluaisivatkin osallistua yhteiskunnalliseen keskusteluun.

Tästä syystä on tärkeää tarjota moninaisista taustoista tuleville nuorille mahdollisuuksia kuvitella ja toteuttaa parempia, kestävämpiä tulevaisuuksia. Tällä hetkellä eri koulutuspoluilla olevat nuoret on asetettu hyvin erilaisiin asemiin kansalaisvaikuttamisen harjoittelun suhteen. Lukion kansalaiskasvatuksessa korostetaan kriittistä ajattelua, aktiivista yhteiskunnallista osallistumista ja vaikuttamista tulevaisuuden luomiseen, kun taas ammattiin opiskeleville painotetaan passiivista, mukautuvaa kansalaisuutta, valmiutta henkilökohtaiseen joustavuuteen ja työelämän muutoksiin sopeutumiseen (Koski 2009; Nylund ym. 2018). Pluralistisen, moniäänisen demokratian kannalta kaikille nuorille tulee mahdollistaa koulutuksen kautta väylä ja työkaluja heille merkityksellisiin yhteiskunnallisiin keskusteluihin osallistumiseen. 


\section{Kirjallisuus}

Ahola, Paula, Rajala, Antti, Ryynänen, Sanna \& Stetsenko, Anna 2021. Agency formation of youth climate activists: A learning ecology perspective. Esitys konferenssissa European Association of Research on Learning and Instruction. Göteborg. Elokuu, 2021.

Bakhtin, Mikhail 1986. Speech genres and other late essays. University of Texas Press.

Bloch, Ersnt 1986. The principle of hope, volume 1. London: Blackwell

Boulding, Elise 1976. A disarmed world: Problems in imaging the future. Journal of Sociology and Social Welfare 4 (3), 656-668.

Bowman, Benjamin 2019. Imagining future worlds alongside young climate activists: a new framework for research. Fennia - International Journal of Geography 197 (2), 295-305. https://doi.org/10.11143/fennia.85151

Dufva, Mikko, Grabtchak, Anna, Ikäheimo, Hannu-Pekka, Lähdemäki-Pekkinen, Jenna \& Poussa, Liisa 2021. Vaikuta tulevaisuuteen: Haasta, kuvittele ja toimi. Sitra.

Freire, Paolo 1994 [1992]. Pedagogy of hope. London: Continuum

Gutiérrez, Kris, Jurow, Susan, \& Vakil, Sepehr 2020. Social design-based experiments: A utopian methodology for understanding new possibilities for learning. Teoksessa Nasir, Suad, Lee, Carol, Pea, Roy \& McKinney de Royston, Maxine (toim.), Handbook of the cultural foundations of learning. Routledge, 330-347. https://doi.org/10.4324/9780203774977-23

Global Sustainable Development Report 2019. The future is now: Science for achieving sustainable development. New York: United Nations [www-lähde]. < https://sustainabledevelopment.un.org/content/documents/24797GSDR report 2019.pd $\underline{\mathrm{f}}>$ (Luettu 19.4.2021).

Koski, Leena 2009. Vocational curriculum - Morality for the working class? Teoksessa Weil, Markus, Koski, Leena ja Mjelde, Liv (toim). Knowing work: the social relations of working and knowing. New York: Lang, 27-50.

Leiviskä, Anniina, \& Pyy, Iida 2020. The unproductiveness of political conflict in education: A Nussbaumian alternative to agonistic citizenship education. Journal of Philosophy of Education (pre-print). https://doi.org/10.1111/1467-9752.12512

Levitas, Ruth 2013. Utopia as method: The imaginary reconstitution of society. London: Palgrave. https://doi.org/10.1057/9781137314253

Mehtäläinen, Jouko, Niilo-Rämä, Mikko \& Nissinen, Virva 2017. Nuorten yhteiskunnalliset tiedot,osallistuminen ja asenteet. Kansainvälisen ICCS 2016 -tutkimuksen päätulokset. Koulutuksen tutkimuslaitos.

Meriläinen, Niina \& Piispa, Mikko 2020. “Antaa isojen herrojen ja rouvien päättää” lasten ja nuorten oikeudet ja osallisuus ilmastonmuutoksen ajassa. Teoksessa Pekkarinen, Elina ja Tuukkanen, Terhi (toim.) Maapallon tulevaisuus ja lapsen oikeudet. Lapsiasiavaltuutetun toimiston julkaisuja 4, 124-136.

Moss, Peter 2014. Transformative change and real utopias in early childhood education: A story of democracy, experimentation and potentiality. London: Routledge. https://doi.org/10.4324/9781315779904

Männistö, Perttu 2020. The state of democracy in Finnish primary school education. JYU Dissertations, 307. Jyväskylä: Jyväskylän yliopisto.

Nylund, Mattias, Rosvall, Per-Åke, Eiríksdóttir, Elsa, Holm, Ann-Sofie, Isopahkala-Bouret, Ulpukka, Niemi, Anna-Maija ja Ragnarsdóttir, Guðrún 2018. The academic-vocational 
divide in three Nordic countries: Implications for social class and gender. Education Inquiry 9 (5), 97-121. https://doi.org/10.1080/20004508.2018.1424490

Penuel, William, Riedy, Robbin, Barber, Michael, Peurach, David, LeBouef, Whitney \& Clark, Tiffany 2020. Principles of collaborative education research with stakeholders: Toward requirements for a new research and development infrastructure. Review of Educational Research 90 (5), 627-674. https://doi.org/10.3102/0034654320938126

Piispa, Mikko, Ojajärvi, Anni \& Kiilakoski, Tomi 2020. Tulevaisuususko hukassa? Nuoret ilmastoaktivistit ja keskustelu tulevaisuudesta. Sitra.

Rajala, Antti 2021. Book review of Utopia as method: The imaginary reconstitution of society, by Levitas. Mind, Culture, \& Activity 28 (1), 82-88. https://doi.org/10.1080/10749039.2021.1883670

Rajala, Antti, Esteban-Guitart, Moises \& Cole, Mike 2020. Utopian methodology: Researching educational interventions over multiple timescales. Esitys konferenssissa EELS8 Conference. Oslo yliopisto, Norja, 24. syyskuuta, 2020.

Rajala, Antti, Hilppö, Jaakko, Lipponen, Lasse, \& Kumpulainen, Kristiina 2013. Expanding the chronotopes of schooling for promotion of students' agency. Teoksessa Erstad, Ola \& Sefton-Green, Julian (toim.) Learning Lives: Transactions, technologies, and learner identity. Cambridge University Press, 107-125. https://doi.org/10.1017/CBO9781139026239.009

Rautiainen, Matti \& Raiker, Andrea 2020. Changing society, changing teacher education. Teoksessa Raiker, Andrea, Rautiainen, Matti \& Saqipi, Blerim (toim.) Teacher education and the development of democratic citizenship in Europe. London: Routledge, 116. https://doi.org/10.4324/9780429030550-1

Roy, Arundhati 2020. The pandemic is a portal. Financial Times 3.3.2020 [www-lähde]. < https://www.ft.com/content/10d8f5e8-74eb-11ea-95fe-fcd274e920ca $>$ (Luettu, 24.9.2021).

Saloranta, Seppo 2017. Koulun toimintakulttuurin merkitys kestävän kehityksen kasvatuksen toteuttamisessa perusopetuksen vuosiluokkien 1-6 kouluissa. Helsinki: Helsingin yliopisto.

Sannino, Annalisa 2020. Enacting the utopia of eradicating homelessness: Toward a new generation of activity-theoretical studies of learning. Studies in Continuing Education 42 (2), 163-179. https://doi.org/10.1080/0158037X.2020.1725459

Schulz, Wolfram, Ainley, John, Fraillon, Julian, Losito, Bruno, Agrusti, Gabriella \& Friedman, Tim 2018. Becoming citizens in a changing world: IEA International Civic and Citizenship Education Study 2016 international report. Springer Nature. https://doi.org/10.1007/978-3-319-73963-2

Secretariat of the Convention on Biological Diversity (2020). Global Biodiversity Outlook 5 [www-lähde]. < www.cbd.int/GBO5 $>($ Luettu 19.4.2021).

Steffen, Will, Richardson, Katherine, Rockström, Johan, Cornell, Sarah, Fetzer, Ingo, Bennett, Elena \& Sörlin, Sverker 2015. Planetary boundaries: Guiding human development on a changing planet. Science 347 (6223). https://doi.org/10.1126/science.1259855

Taylor, Affrika, \& Pacini-Ketchabaw, Veronica 2015. Learning with children, ants, and worms in the Anthropocene: Towards a common world pedagogy of multispecies vulnerability. Pedagogy, Culture \& Society 23 (4), 507-529. https://doi.org/10.1080/14681366.2015.1039050

United Nations Environment Programme 2020. Emissions Gap Report 2020 [www-lähde]. $<$ https://www.unep.org/emissions-gap-report-2020 > (Luettu 19.04.2021).

Värri, Veli-Matti 2018. Kasvatus ekokriisin aikakaudella. Tampere: Vastapaino. 
Wahlström, Mattias, Sommer, Moritz, Kocyba, Piotr, De Vydt, Michiel, de Moor, Joost, Davies, Stephen, Wouters, Ruud 2019. Protest for a future: Composition, mobilization and motives of the participants in Fridays For Future climate protests on 15 March, 2019 in 13 European Cities. Keele, UK: Keele University e-Prints.

Wright, Erik 2007. Guidelines for envisioning real utopias, Soundings 35, 26-39. https://doi.org/10.3898/136266207820465778

Wright, Erik 2010. Envisioning real utopias (Vol. 98). London: Verso.

FT, dosentti Antti Rajala on Suomen Akatemian tutkijatohtori Oulun yliopistossa. Rajala johtaa Konkreettien utopioiden pedagogiikka -tutkimushanketta.

FM Jarmo Lehtinen työskentelee Lempäälän lukiossa historian ja yhteiskuntaopin lehtorina ja Ohjatusti kohti tulevaisuuden työelämää-ESR-hankkeen työelämäkoordinaattorina, sekä Ilmastosoturien ohjaavana opettajana.

Professori, dosentti, KT Elina Lehtomäki työskentelee Oulun yliopiston kasvatustieteiden tiedekunnassa globaalikasvatuksen ja kansainvälisen yhteistyön tehtävissä.

FM Pihla Soinnunmaa on väitöskirjatutkijana Konkreettien utopioiden pedagogiikka -hankkeessa ja tekee jatko-opintojaan Helsingin yliopistolla Ympäristöalan tieteidenvälisessä tohtoriohjelmassa.

TM, ympäristökasvattaja (EAT) Mikael Sorri työskentelee Etelä-Tapiolan lukiossa elämänkatsomustiedon, filosofian ja uskonnon opettajana.

FM Riikka Suhonen on kansainvälisyyskoordinaattori ammatillisessa oppilaitoksessa Luksiassa, Länsi-Uudenmaan koulutuskuntayhtymässä ja väitöskirjatutkija Helsingin yliopiston Koulun, kasvatuksen, yhteiskunnan ja kulttuurin tohtoriohjelmassa.

Kiitämme Suomen Akatemian projektia numero 331413 sekä Maj ja Tor Nesslinging säätiötä tutkimuksen rahoituksesta. 